\title{
PENDEKATAN PEMBELAJARAN PARAMASASTRA JAWA DI SEKOLAH DASAR
}

\author{
Endang Sri Maruti *
}

\begin{abstract}
Learning paramasastra (grammar), especially paramasastra Java, in the $S B C$ between two poles. On the one hand, learning grammar is important to determine how the students' understanding of the Java language, on the other hand grammar learning integrable in four aspects already existing skills in the curriculum. Determination of the polemical stance in the face of an important thing to do, so that the teacher can determine the approach to be used in learning.
\end{abstract}

Keywords: approach, learning, paramasastra, the Java language

\begin{abstract}
Abstrak
Pembelajaran paramasastra (tata bahasa), khususnya paramasastra Jawa, dalam KTSP antara dua kutub. Di satu sisi, pembelajaran tata bahasa itu penting untuk menentukan seberapa dalam pemahaman siswa terhadap bahasa Jawa, di sisi lain pembelajaran tata bahasa sudah terintegralkan dalam empat aspek keterampilan yang ada dalam kurikulum. Penentuan sikap dalam menghadapi polemik tersebut penting untuk dilakukan, supaya para guru dapat menentukan pendekatan yang akan digunakan dalam pembelajaran.
\end{abstract}

Kata Kunci: pendekatan, pembelajaran, paramasastra, bahasa jawa

\section{A. Pendahuluan}

Hingga kini pengajaran tata bahasa masih menimbulkan polemik. Ada anggapan bahwa Kurikulum Berbasis Kompetensi (KBK) atau yang kemudian disempurnakan lagi menjadi Kurikulum Tingkat Satuan Pendidikan (KTSP) tidak mementingkan aspek kebahasaan (tata bahasa) karena aspek tersebut sudah tidak tampak lagi secara eksplisit dalam Standar Isi (Yulianto, 2008:3).

Para pendukung pengajaran tata bahasa implisit beranggapan bahwa pengajaran eksplisit hanya akan menghambat aspek komunikatif para pembelajar. Selain itu, mereka berpendapat bahwa pengajaran tata bahasa seharusnya terintegrasi dalam pengajaran keterampilan berbahasa yang lain. Menurut mereka, untuk dapat membaca atau menulis dibutuhkan pula pengetahuan ketatabahasaan, sehingga sebaiknya pengajaran ketatabahasaan itu dilakukan secara integral dengan yang lain.

Meskipun demikian, pendukung pengajaran tata bahasa eksplisit menganggap tata bahasa merupakan komponen penting yang menentukan apakah pembelajar telah menguasai bahasa yang dipelajarinya atau tidak. Mahir berbahasa tidak hanya berarti menguasai deretan kosakata, melainkan juga struktur yang

* Endang Sri Maruti adalah dosen PGSD IKIP PGRI Madiun 
merangkaikannya. Lebih jauh, pengajaran tata bahasa juga dianggap dapat membantu pembelajar untuk menentukan struktur yang pas atau cocok dengan konteks penggunaannya.

Untuk itu, berikut ini secara berturut-turut akan dibahas tentang pembelajaran tata bahasa Jawa, prinsip pembelajaran tata bahasa Jawa, dan pendekatan pembelajaran tata bahasa Jawa yang integratif.

\section{B. Pembahasan}

\section{Pembelajaran Tata Bahasa Jawa}

Tata bahasa adalah ilmu yang mempelajari kaidah-kaidah yang mengatur penggunaan bahasa (Yulianto, 2008:5). Sedangkan pembelajaran tata bahasa Jawa adalah proses pembelajaran di kelas yang mengajarkan tentang kaidah-kaidah yang mengatur penggunaan bahasa Jawa, yakni tentang kaidah fonetik, morfologi, sintaktik, dan juga semantik. Lalu mengapa perlu adanya pembelajaran tata bahasa Jawa?

Dalam pendahuluan sudah sedikit dijelaskan tentang polemik pembelajaran tata bahasa. Kali ini, akan dijelaskan secara terperinci alasan-alasan apa yang membuat komponen tata bahasa itu penting diajarkan. Menurut Swan (2002:151), ada dua alasan yang sangat penting untuk mengajarkan komponen tata bahasa, yakni comprehensibility (kemampuan untuk mengerti) dan juga acceptability (kemampuan untuk menerima).

\section{Comprehensibility}

Untuk dapat mengetahui bagaimana cara membangun dan menggunakan struktur tertentu yang digunakan untuk komunikasi merupakan tujuan utama pembelajaran komponen tata bahasa. Tanpa pengetahuan tata bahasa, sulit untuk membuat kalimat yang dapat dipahami.

\section{Acceptability}

Dalam beberapa konteks tertentu, siswa seringkali mempunyai anggapan yang kurang tepat terhadap suatu pernyataan sehingga dapat menghambat integrasi dan membangkitkan prasangka. Oleh karena itu, selain komprehensif, perlu juga ditingkatkan kemampuan dalam hal penerimaan ketepatan tata bahasa, ketepatan gramatikal, misalnya.

Adapun beberapa tujuan dari pembelajaran tata bahasa, yakni seperti di bawah ini.

1. Pengetahuan mengenai tata bahasa biasanya menjadi asas di dalam logika. Mereka yang mengetahui tata bahasa akan dapat menyusun kalimat dengan baik, benar, dan juga rapi.

2. Pengetahuan tentang tata bahasa membantu siswa untuk berbicara (dan mengarang) dengan lancar, benar dan mudah difahami oleh orang lain.

3. Pengetahuan tentang tata bahasa mempermudah siswa dalam memahami suatu kalimat dengan cara menganalisis kedudukannya.

4. Pengetahuan tentang tata bahasa berguna bagi orang-orang dewasa atau pelajar-pelajar di perguruan tinggi, terutama apabila pelajar bahasa asing.

5. Pengetahuan tentang tata bahasa membantu siswa dalam menilai suatu kalimat apakah sudah benar atau belum.

Berdasarkan alasan serta tujuan pembelajaran tata bahasa tersebut, maka perlulah bagi guru untuk mengajarkan tata bahasa dengan baik, sesuai dengan aturan, dan tidak hanya asal-asalan saja. 


\section{Prinsip Pembelajaran Tata Bahasa Jawa}

Seperti yang telah dijelaskan sebelumnya bahwa tata bahasa diajarkan hanya untuk membetulkan kesalahan ujaran siswa. Dengan demikian, porsi pembelajaran tata bahasa bukan menjadi yang utama. Komponen-komponen tata bahasa menjadi sarana untuk memahami dan menggunakan bahasa untuk tujuan tertentu.

Orang sering menganggap tata bahasa sebagai sistem kesatuan yang utuh, yang semuanya harus dipelajari jika ingin mengerti dengan baik. Hal ini adalah ilusi semata. Tata bahasa bukanlah seperti mesin mobil, di mana kesalahan dalam satu komponen seperti pengapian atau pasokan bahan bakar dapat menyebabkan gangguan fatal. Kenyataannya, tata bahasa dianggap sebagai akumulasi unsur yang berbeda, sistematis, lalu dihubungkan satu sama lain bisa secara erat ataupun longgar, beberapa unsur boleh juga dilepas (Swan, 2002:153).

Secara khusus prinsip-prinsip pembelajaran tata bahasa Jawa dapat diungkapkan sebagai berikut. Pertama, pembelajaran tata bahasa merupakan pelatihan pemahaman dan penggunaan bahasa yang bermakna sesuai dengan keperluan komunikasi. Dalam hal ini, kegiatan utama pembelajaran komponen tata bahasa melalui pemberian latihan yang terus-menerus dalam berbagai situasi kebahasaan yang bermakna. Pelatihan itu harus diarahkan untuk mendukung, baik kemampuan aspek pemahamam maupun aspek penggunaan. Hal ini sejalan dengan Ellis (2002:167), bahwa pendekatan terbaik dalam pembelajaran tata bahasa adalah dengan melakukan banyak latihan yang bertujuan untuk menimbulkan kesadaran dalam berbahasa yang komunikatif.

Kedua, pembelajaran tata bahasa terintegrasi ke dalam pembelajaran keterampilan berbahasa. Jadi, komponen tata bahasa tidak diajarkan secara mandiri. Dengan demikian, pembelajaran tata bahasa terfokus kepada penggunaan bahasa secara fungsional dan bermakna sesuai dengan tujuan dan keperluan komunikasi.

Ketiga, pembelajaran komponen tata bahasa tidak menganut tata urutan pembelajaran secara linguistis. Komponen fonologi tidak harus diajarkan lebih dahulu dibandingkan dengan komponen morfologi ataupun sintaksis. Dalam hal ini, pemilihan bahan yang tepat dapat menjadi kunci keberhasilan pembelajaran tata bahasa.

Berdasarkan ketiga hal di atas, pengajaran komponen tata bahasa Jawa akan bergantung pada keadaan guru dan peserta didiknya. Apapun situasinya, kita harus memastikan bahwa kita hanya mengajarkan poin tata bahasa yang kita butuhkan saja, sehingga pembelajaran menjadi lebih efektif. Selain itu, kita akan dapat mengajarkan bahasa Jawa secara keseluruhan, dan tidak hanya mengajar tata bahasa saja.

Pada dasarnya pembelajaran tata bahasa Jawa sedikit berbeda dengan pengajaran tata bahasa Indonesia. Secara fonologis, dalam bahasa Jawa terdapat peristiwa morfofonemik (Adipitoyo, 1991:2), yakni perubahan fonemis akibat proses morfemis. Contohnya:

$$
\{\text { ke- }\}+\{\text { udan }\}+\{- \text { an }\}-\longrightarrow \text { kudanan //kudannan// 'kehujanan' }
$$

Dalam tataran morfologis misalnya pembentukan kata ulang seperti:

$$
\{\text { RDLSS }\}+\text { celuk - - - celak-celuk [cəla?-cəlU?] 'memanggil-manggil' }
$$

Komponen sintaktis misalnya dalam pembentukan kalimat efektif itu setidaktidaknya terdiri dari jejer 'subjek' dan wasesa 'predikat'. Contohnya: 


\section{$\underline{\text { Aku duwe pitik }}$ \\ $\mathrm{J} / \mathrm{S}$ W/P L/O}

Dalam tataran semantik, bisa diajarkan tentang relasi makna seperti antonim, sinonim, homonim, hiponim, dan lain sebagainya.

\section{Pendekatan Pembelajaran Tata Bahasa Jawa}

Pendekatan ialah sesuatu sikap terhadap pengajaran dan pembelajaran. Istilah pendekatan di dalam pengajaran bahasa merupakan suatu kumpulan prinsip yang berkaitan dengan bahasa, pengajaran bahasa dan pembelajaran bahasa tersebut. Jadi, pendekatan merupakan suatu pandangan mengenai apa sebenarnya bahasa itu, cara bahasa itu digunakan, cara bahasa itu diperoleh, bagaimana bahasa itu dilahirkan dan difahami, serta permasalahan-permasalahan yang muncul tentang suatu bahasa.

Suatu pendekatan harus berlandaskan pada sebuah teori bahasa, teori pengajaran bahasa dan teori pembelajaran bahasa tertentu. Kalau dulu orang menganggap bahasa terdiri atas rumus-rumus dan kita belajar dengan menghafal rumus-rumus itu, maka guru akan mendekati pengajaran bahasa dengan menggunakan rumus-rumus tersebut. Sebaliknya kalau bahasa dianggap sebagai suatu keseluruhan yang mempunyai beberapa unsur yang berlainan, maka pengajaran bahasa akan dimulakan dengan mengamati keseluruhan konteks itu dan unsur-unsurnya, baru kemudian mempelajari bagaimana keseluruhan unsur tersebut bergabung menjadi suatu perhubungan.

Berdasarkan penjelasan di atas, dapat disimpulkan bahawa pendekatan mengenai bahasa dan proses pembelajaran bahasa itu dapat dijadikan asas untuk menyusun metode pengajaran. Selanjutnya barulah menggunakan teknik yang bermacam-macam.

Berdasarkan atas teori-teori pemerolehan dan pembelajaran bahasa, terdapat tiga jenis pendekatan di dalam pengajaran bahasa, antara lain: (1) pendekatan deduktif; (2) pendekatan induktif; dan (3) pendekatan enklitik.

\section{a. Pendekatan Deduktif}

Pendekatan deduktif ditandai dengan pemaparan konsep, definisi dan istilah-istilah pada bagian awal pembelajaran. Pendekatan deduktif dilandasi oleh suatu pemikiran bahwa proses pembelajaran akan berlangsung dengan baik bila siswa telah mengetahui wilayah persoalannya dan konsep dasarnya (Suwarna, 2008:56).

Pendekatan deduktif merupakan pengajaran tata bahasa sebelum menyentuh pada ranah penggunaan bahasa. Dalam proses pengajarannya, pendekatan ini mendahulukan generalisasi baru kemudian diberikan contoh-contoh penggunaanya. Pelajaran dimulai dengan diberikannya rumus-rumus tata bahasa oleh guru kepada siswa. Setelah itu, barulah diberi contoh-contoh penggunaan rumus-rumus itu di dalam pemakaian bahasa. Jadi, siswa tinggal meniru dan menghafalkannya. Ada beberapa hal yang perlu dipertimbangkan apabila menggunakan pendekatan deduktif dalam pembelajaran tata bahasa Jawa, yakni:

a. generalisasi atau rumus-rumus tata bahasa yang akan disampaikan pada awal pelajaran haruslah dinyatakan dengan mudah dan jelas supaya dapat difahami siswa. 
b. setelah diberi rumus, barulah diberi contoh-contoh yang banyak dan harus sesuai dengan rumus.

c. contoh-contoh tersebut hendaklah diambil dari semua kemungkinan penggunaan bahasa.

Seperti yang dikatakan di atas, dalam pendekatan deduktif, rumus-rumus tata bahasa, pola-pola, dan generalisasi tertentu diberikan terlebih dahulu dalam pembelajaran, baru kemudian diberi contoh penerapannya, dan terakhir dengan penugasan, yakni siswa diberi bahan untuk kemudian menerapkan rumus-rumus yang telah diperolehnya.

Contoh penerapan pendekatan deduktif misalnya dalam pengajaran tentang kata seru (tembung panguwuh) dalam bahasa Jawa. Guru menerangkan terlebih dahulu tentang pengertian, ciri-ciri, fungsi, cara penulisan, dan terakhir contoh kalimat yang mengandung kata seru. Jadi, dalam pengajaran ini, siswa hanya bisa menerima, meniru, dan menghafalkannya saja.

\section{b. Pendekatan Induktif}

Pendekatan induktif diawali dengan pemberian contoh struktur kalimat yang mengandung penggunaan unsur-unsur tata bahasa Jawa yang akan dipelajari. Kemudian latihan masih tetap berlanjut dengan memberikan beberapa tugas. Bersamaan dengan itu, siswa dibimbing dan dilatih untuk memperhatikan struktur-struktur dalam penugasan tersebut, dan terakhir barulah siswa membuat generalisasi atau rumusan sendiri. Dengan itu, siswa dapat memahami pola atau struktur dalam contoh kalimat yang lain.

Dampak lain dari penerapan pendekatan ini adalah siswa mendapat kesempatan untuk memantau, menilai, dan mengembangkan potensi dirinya (Nunan, 2002:144).

Ada beberapa hal yang perlu diperhatikan dalam pendekatan ini, di antaranya:

a. guru perlu menguasai struktur tata bahasa yang hendak disampaikan.

b. berdasarkan atas unsur-unsur tata bahasa yang saling terkait, guru boleh menyusun suatu langkah yang teratur untuk mempermudah siswa dalam pemahaman konsep.

c. guru hendaknya menyusun sebuah strategi supaya dapat membantu siswa dalam membentuk konsep dan dilanjutkan dengan membuat generalisasi mengenai tata bahasa seperti apa yang dikehendaki.

d. siswa hendaknya banyak melakukan latihan untuk menguji dan mempertegas pemahamannya tentang apa yang telah digeneralisasikan.

Contoh penerapannya adalah dalam pembelajaran tentang pembentukan kata ulang (dwilingga) dalam bahasa Jawa. Pada awalnya guru memberikan contoh-contoh kalimat yang mengandung berbagai kata ulang. Setelah mencermati dan juga membuat contoh kalimat sendiri, siswa dapat menyebutkan jenis-jenis, cara penulisan, dan fungsi kata ulang bahasa Jawa. Guru harus senantiasa membimbing dan mengarahkan siswa dalam proses generalisasi.

\section{c. Pendekatan Enklitik}

Jika sebelumnya dijelaskan tentang pendekatan yang kontras, yakni antara deduktif dan induktif. Kedua pendekatan ini bisa dikatakan nyaris sama, tidak bisa dikatakan pendekatan deduktif lebih baik daripada pendekatan induktif, ataupun 
sebaliknya, karena masing-masing mempunyai keunggulan serta kelemahan. Sebagai jalan tengahnya, maka munculah suatu pendekatan yang menggabungkan keunggulan-keunggulan dari kedua pendekatan yang kontras tersebut, sehingga menjadi lebih berkesan dan juga menarik. Pendekatan seperti ini disebut dengan pendekatan enklitik.

Dalam pendekatan enklitik, guru bahasa bisa memulai pelajaran dengan memberi contoh-contoh tentang materi yang menjadi tujuan pembelajaran kepada siswa. Setelah itu, siswa dibimbing untuk membuat suatu pernyataan (menggeneralisasikan) tentang tata bahasa yang sedang dipelajari. Tidak berhenti sampai di situ, siswa diminta untuk memberi penjelasan tentang konsep materi tata bahasa lengkap dengan contoh-contohnya.

Misalnya dalam pembelajaran materi sinonim (dasanama) dalam bahasa Jawa. Siswa terlebih dahulu diberi contoh-contoh kalimat yang mengandung sinonim. Bersama-sama dengan guru, siswa menggenaralisasikan konsep tentang pengertian serta penggunaan sinonim dalam kalimat. Setelah itu, siswa harus menjelaskan konsep yang diterimanya itu lengkap beserta contoh-contoh yang benar dan sesuai.

\section{Simpulan}

Kita perlu menyadari bahwa siswa itu dapat menyerap dan menerima materi yang kita ajarkan dengan gaya-gaya serta pendekatan yang berbeda-beda antara satu dengan yang lainnya. Sehingga tidak bisa dikatakan jika pendekatan satu cocok untuk semua siswa dalam satu kelas, ataupun dalam satu sekolah. Jadi, guru perlu untuk memilah-milah dan mencoba berbagai pendekatan yang sesuai dengan kebutuhan siswa.

Berdasarkan jenis pendekatan alternatif dalam pembelajaran tata bahasa Jawa di atas, dapat diambil simpulan, yakni: pertama, kita tidak perlu menekankan kegiatan-kegiatan yang tidak bermakna dalam pengajaran bahasa yang akan membuat siswa malas untuk berpikir. Kedua, kita mungkin akan lebih mengutamakan usaha siswa dalam proses berpikirnya, sehingga mereka bisa masalahnya sendiri, dan hal ini akan juga dapat meningkatkan daya pikir siswa.

Ketiga, siswa haruslah diberi contoh pemakaian bahasa yang nyata, misalnya dalam majalah, koran, atau media cetak yang lain. Ketiga, kita harus lebih banyak menggunakan pendekatan afektif dalam proses pembelajaran tata bahasa. 


\section{DAFTAR PUSTAKA}

Adipitoyo, Sugeng dkk. 1999. Morfofonemik Bahasa Jawa Dialek Surabaya. Jakarta: Pusat Pembinaan dan Pengembangan Bahasa.

Yulianto, Bambang. 2008. Aspek Kebahasaan dan Pembelajarannya. Surabaya: Unesa University Press

Ellis, Rod. 2002. "Grammar Teaching: Practice or Consciousness Raising?". Richards dan Renandya (Ed). Methodology in Language Teaching. New York: Cambridge University Press.

Nunan, David. 2002. "Learner Strategy in the Calssroom: An Action Research Study”. Richards dan Renandya (Ed). Methodology in Language Teaching. New York: Cambridge University Press.

Richards, Jack C. 2002. "Addressing the Grammar Gap in Task Work”. Richards dan Renandya (Ed). Methodology in Language Teaching. New York: Cambridge University Press.

Suwarna. 2008. Macam-Macam Pendekatan Pembelajaran. (Online) (http://rochmadunnes.blogspot.com/2008/01/penggunaan-pola-pikir-induktifdeduktif.html, diakses tanggal 02 Desember 2011).

Swan, Micheal. 2002. "Seven Bad Reasons for teaching Grammar-and Two Good Ones". Richards dan Renandya (Ed). Methodology in Language Teaching. New York: Cambridge University Press. 